\title{
PEMBERIAN INFORMASI DASAR POSYANDU MELALUI KEGIATAN PENYEGARAN KADER DALAM MENINGKATKAN PENGETAHUAN KADER DI PUSKESMAS PELABUHAN SAMBAS KOTA SIBOLGA (The presentation of Posyandu basic information throught cadre refresher activity was increase knowledge of cadres in Puskesmas Pelabuhan Sambas at Sibolga City)
}

\author{
Bibi Ahmad Chahyanto $^{1^{*}}$, Donna Pandiangan' ${ }^{2}$ Edwin Sovvan Aritonang ${ }^{3}$, Mesa Laruska \\ ${ }^{1}$ Bidang Kesehatan Masyarakat, Dinas Kesehatan Kota Sibolga, Jl. F.L. Tobing No. 36, Sibolga, \\ E-mail : bibiahmadchahyanto@gmail.com \\ ${ }^{2}$ Rumah Sakit Umum Daerah Dr. Ferdinand Lumban Tobing, Jl. F.L. Tobing No. 35, Sibolga \\ E-mail : dozza08pandia@gmail.com \\ ${ }^{3}$ UPTD Puskesmas Pelabuhan Sambas, Jl. Horas Ujung Kecamatan Sibolga Sambas, Sibolga \\ E-mail : faizrasyiqart1@gmail.com \\ ${ }^{4}$ UPTD Puskesmas Pelabuhan Sambas, Jl. Horas Ujung Kecamatan Sibolga Sambas, Sibolga \\ E-mail : mesalaruska@gmail.com
}

\begin{abstract}
ABSTRAK
Salah satu kendala yang dihadapi dalam pelaksanaan Posyandu adalah sering terjadinya pergantian kader posyandu. Penelitian bertujuan untuk mengetahui hubungan pemberian informasi dasar posyandu melalui kegiatan penyegaran kader terhadap pengetahuan kader di Puskesmas Pelabuhan Sambas, Kecamatan Sibolga Sambas, Kota Sibolga. Penelitian pra eksperimental ini menggunakan rancangan one group pretest-posttest dan dilaksanakan pada bulan Maret 2017. Jumlah kader posyandu yang menjadi responden sebanyak 51 orang di Wilayah Kerja Puskesmas Pelabuhan Sambas. Pemberian informasi dasar posyandu dilakukan sebanyak 1 kali dengan durasi 3 jam dengan metode ceramah dan tanya jawab menggunakan media gambar pada slide show power point. Sebelum dan setelah pemberian informasi, responden diberi pertanyaan pretest dan posttest. Hasil penelitian membuktikan tingkat pendidikan $(p=0,000)$ dan lama menjadi kader $(p=0,002)$ secara signifikan berhubungan dengan peningkatan pengetahuan kader posyandu terkait informasi dasar posyandu. Pemberian informasi dasar posyandu secara signifikan dapat meningkatkan pengetahuan kader posyandu $(p=0,000)$. Disarankan untuk melakukan penelitian dengan durasi intervensi lebih panjang dan dengan variabel lain.
\end{abstract}

Kata kunci : Kader, pengetahuan, penyegaran kader

\begin{abstract}
One posyandu constraint is the frequent change of posyandu cadres. This study aimed to determine the effect of posyandu basic information presentation through cadre refresher to cadre knowledge in Puskesmas Pelabuhan Sambas, Sibolga Sambas Sub-district, Sibolga City. This
\end{abstract}

pre experimental study was used a one group pretestpostest design and the study was conducted from March 2017. The number of posyandu cadres who become respondents were 51 people in Puskesmas Pelabuhan Sambas. Method of this study was lecture and active discussion using slide show power point media. The presentation of posyandu basic information was 1 time performed with 3 hours duration. Before and after presentation, respondents were given a pre and post test questions. The results showed the level of education $(p=0,000)$ and long time as a cadre ( $p=-, 002)$ was significantly to increased knowledfe of posyandu cadres related to basic information posyandu. The presentation of posyandu basic information was increased knowledge of posyandu cadres $(p=0,000)$. Need to do re-research with a longer duration of intervention and with other variables.

Keywords: Cadres, knowledge, upgrading

\section{PENDAHULUAN}

Pos Pelayanan Terpadu (Posyandu) merupakan salah satu bentuk Upaya Kesehatan Berbasis Masyarakat (UKBM) yang dikelola dan diselenggarakan dari, oleh, untuk dan bersama masyarakat dalam penyelenggaraan pembangunan kesehatan guna memberdayakan masyarakat dan memberikan kemudahan kepada masyarakat dalam memperoleh pelayanan kesehatan dasar/sosial dasar untuk mempercepat penurunan Angka Kematian Ibu (AKI) dan Angka Kematian Bayi (AKB). Peran posyandu

${ }^{*}$ Penulis untuk korespondensi: bibiahmadchahyanto@gmail.com 
menjadi sangat penting karena posyandu termasuk sebagai salah satu tempat pelayanan kesehatan yang langsung bersentuhan dengan masyarakat di level bawah. ${ }^{1}$

Keberlangsungan kegiatan posyandu digerakkan oleh kader yang berasal dari anggota masyarakat setempat, berminat dan bersedia menjadi kader, bersedia bekerja secara sukarela serta memliki kemampuan dan waktu luang. Kader posyandu bertugas mulai dari mempersiapkan, melaksanakan kegiatan posyandu, menggerakkan masyarakat, hingga membuat laporan. Kader bertindak sebagai penggerak utama kelancaran kegiatan posyandu sehingga perlu mendapatkan bekal pengetahuan dan keterampilan yang benar khususnya yang berhubungan dengan informasi dasar posyandu. ${ }^{2,1}$

Puskesmas Pelabuhan Sambas merupakan salah satu Unit Pelayanan Teknis (UPT) Dinas Kesehatan Kota Sibolga yang membawahi wilayah kerja Kecamatan Sibolga Sambas. Puskesmas ini membawahi 21 posyandu balita aktif yang tersebar di 4 kelurahan. Setiap posyandu terdiri dari 5 kader aktif yang bertugas setiap bulannya. ${ }^{3}$

Hasil studi pendahuluan di Puskesmas Pelabuhan Sambas menunjukkan bahwa salah satu kendala yang dihadapi dalam pelaksanaan posyandu terkait dengan kader adalah sering terjadinya pergantian kader posyandu tanpa diikuti dengan pelatihan, sehingga pengetahuan dan keterampilan kader mengenai informasi dasar posyandu kurang memadai. Menurut Sutiani et al. sebanyak 75,0\% dari kader baru termasuk ke dalam kategori kader yang kurang terampil. Hal ini berarti, kader lama lebih terampil dibandingkan kader baru. ${ }^{4}$ Putra dan Yuliatni menambahkan bahwa masa kerja kader posyandu yang lama belum tentu memiliki kinerja yang baik apabila tidak diiringi dengan pelatihan yang diperoleh kader. ${ }^{5}$ Oleh karena itu, perlu dilakukan pemberian informasi dasar posyandu kepada kader posyandu baru maupun kader posyandu lama melalui kegiatan penyegaran kader.

Penelitian ini bertujuan untuk mengetahui hubungan pemberian informasi dasar posyandu melalui kegiatan penyegaran kader terhadap pengetahuan kader di Puskesmas Pelabuhan
Sambas, Kecamatan Sibolga Sambas, Kota Sibolga.

\section{METODE}

Desain studi yang digunakan adalah pra eksperimental dengan rancangan one group pretest-postes. Proses pengumpulan dan pengolahan data dilakukan pada bulan Maret 2017 di wilayah kerja Puskesmas Pelabuhan Sambas, Kecamatan Sibolga Sambas, Kota Sibolga. Jumlah populasi target pada penelitian ini sebanyak 105 orang kader yang berasal dari 21 Posyandu. Jumlah responden yang menjadi sampel pada penelitian ini sebanyak 51 orang yang dipilih secara purposif 2 - 3 kader dari 20 posyandu. Terdapat 1 posyandu yang seluruh kadernya tereksklusi sebagai responden.

Kriteria inklusi kader posyandu yang menjadi responden kegiatan ini yaitu : 1)bersedia menjadi responden, dan 2)bersedia mengikuti kegiatan penyegaran kader posyandu yang dilaksanakan oleh UPTD Puskesmas Pelabuhan Sambas dari awal hingga akhir. Kriteria eksklusi responden penelitian adalah kader datang terlambat dalam kegiatan penyegaran dan tidak mengikuti pretest.

Variabel yang diwawancarai dalam penelitian ini adalah pengetahuan kader terhadap informasi dasar posyandu sebelum dan sesudah diberikan informasi dasar posyandu dengan metode ceramah dan tanya jawab menggunakan media gambar yang tersaji pada slide show power point. Penyegaran kader posyandu dilakukan sebanyak 1 kali dengan durasi 3 jam. Untuk mengetahui tingkat keberhasilan kegiatan dan pengetahuan kader posyandu setelah adanya penyegaran, maka dilakukan suatu pengukuran yang terstruktur menggunakan kuesioner yang berisi pertanyaan pretest dan posttest. Pertanyaan diberikan sebelum dan setelah intervensi pemberian materi informasi dasar posyandu. Pertanyaan terdiri dari 10 item penting pertanyaan tertutup terkait kegiatan posyandu yang sangat mendasar yang disarikan dari Buku Panduan Kader Posyandu. ${ }^{1}$

Jawaban dari setiap pertanyaan diberi skor, dengan penilaian skor dari jawaban benar $=1$ dan $\operatorname{salah}=0$. Pengetahuan terhadap informasi dasar posyandu kemudian dikategorikan menjadi 
tiga, yaitu baik ( $>80 \%$ jawaban benar, skor $>8)$, cukup (60-80\% jawaban benar, skor 6-8), dan kurang $(<60 \%$ jawaban benar, skor $<6) .{ }^{6,7}$

Variabel lain yang ditanyakan kepada responden dengan menggunakan instrumen kuesioner pertanyaan terbuka adalah karakteristik responden yang meliputi umur, pendidikan, pekerjaan, dan lama menjadi kader posyandu. Pengisian kuesioner dilakukan oleh peneliti dengan menanyakan secara secara terstruktur kepada responden.

Seluruh data yang terkumpul selanjutnya dimasukkan (entry) dan ditabulasi sebagai hasil analisis deskriptif. Perbedaan rata-rata skor pengetahuan sebelum dan sesudah diberikan penyegaran diuji dengan menggunakan uji tes berpasangan (Paired t test) karena memenuhi syarat normalitas dan homogenitas data dengan nilai $p>0,05$. Hubungan antara variabel bebas (umur, pendidikan, pekerjaan) dengan variabel terikat (perubahan pengetahuan informasi dasar posyandu dan skor pengetahuan responden sebelum penyegaran) diuji secara statustik menggunakan uji korelasi spearmen, sedangkan hubungan antara variabel lama menjadi kader dengan variabel perubahan pengetahuan informasi dasar posyandu dan skor pengetahuan responden sebelum penyegaran menggunakan uji korelasi Pearson. Hasil analisis dinyatakan berbeda secara nyata (signifikan) apabila nilai $\mathrm{p}<0,05$.

\section{HASIL DAN PEMBAHASAN}

\section{Karakteristik Responden}

Kader posyandu yang menjadi responden dalam penelitian ini didominasi oleh kader yang termasuk ke dalam kategori dewasa berumur 19 - 44 tahun $(70,6 \%)$, sisanya $(29,4 \%)$ termasuk Pra Lansia umur 45 - 59 tahun (Tabel 1). Sebelum intervensi pemberian materi informasi dasar Posyandu diberikan, lebih dari setengah responden kategori dewasa $(52,8 \%)$ dan pra lansia $(60,0 \%)$ memiliki pengetahuan yang cukup terkait informasi dasar posyandu (Tabel 2).

Umur menandakan tingkat kematangan seseorang baik dalam berfikir maupun dalam bertindak. Penelitian Hapsari dan Veria membuktikan bahwa umur dapat mempengaruhi keaktifan kader posyandu dalam menjalankan tugasnya. ${ }^{8}$ Semakin bertambahnya umur, maka kader akan semakin aktif dalam berkegiatan. Namun perlu diperhatikan juga bahwa umur yang terlalu tua dapat menurunkan kinerja dan keaktifan kader akibat dari kondisi fisik dan kesehatan yang semakin melemah. Oleh karena itu, pemilihan kader posyandu di Wilayah Kerja Puskesmas Pelabuhan Sambas sudah tepat karena terdiri dari usia dewasa dan pra lansia, dengan proporsi terbanyak terdapat pada usia dewasa $(70,6 \%)$. Umur kader tidak terlalu muda dan tidak terlalu tua sehingga diharapkan kader menjadi aktif dalam pelaksanaan posyandu.

Tabel 1. Sebaran kader posyandu berdasarkan karakteristik responden

\begin{tabular}{lcc}
\hline \multicolumn{1}{c}{ Karakteristik } & $\mathrm{n}$ & $\%$ \\
\hline \multicolumn{1}{c}{ Responden } & & \\
Umur & 36 & 70,6 \\
Dewasa & 15 & 29,4 \\
$\quad$ Pra Lansia & & \\
\hline Pendidikan Terakhir & & 7,8 \\
$\quad$ Tamat SD/sederajat & 13 & 25,5 \\
Tamat SMP/sederajat & 34 & 66,7 \\
Tamat & & \\
SMA/sederajat & & \\
\hline Pekerjaan & 45 & 88,2 \\
Tidak Bekerja (IRT) & 6 & 11,8 \\
Bekerja & & \\
\hline Lama Menjadi Kader & 18 & 35,3 \\
$\quad \leq 12$ bulan & 13 & 25,5 \\
13 - 36 bulan & 6 & 11,8 \\
37 - 60 bulan & 9 & 17,6 \\
$>$ 60 bulan & 5 & 9,8 \\
Ragu-ragu (lupa) & $\mathbf{5 1}$ & $\mathbf{1 0 0 , 0}$ \\
\hline$\quad$ TOTAL &
\end{tabular}

Seluruh kader posyandu yang menjadi responden sudah pernah duduk di bangku pendidikan, dengan pendidikan terendahnya adalah Tamat Sekolah Dasar (SD) atau sederajat. Sebaran responden yang berpendidikan terakhir Sekolah Menengah Atas (SMA) atau sederajat memiliki persentase terbesar yaitu $66,7 \%$, sedangkan persentase terendah terdapat pada responden yang 
berpendidikan terakhir SD/sederajat yaitu $7,8 \%$ (Tabel 1).

Hasil penelitian yang ditampilkan pada Tabel 2 membuktikan bahwa sebagian besar responden dengan pendidikan tamat $\mathrm{SD} /$ sederajat memiliki pengetahuan yang kurang $(75,0 \%)$ terkait informasi dasar posyandu sebelum intervensi pemberian materi dilakukan. Sedangkan responden yang tamat SMA/sederajat sebagian besar $(61,8 \%)$ memiliki pengetahuan yang cukup.

Kemenkes RI dalam Buku Panduan Kader Posyandu mengharapkan seluruh kader Posyandu dapat membaca dan menulis huruf latin. ${ }^{1}$ Hasil penelitian ini membuktikan bahwa seluruh kader posyandu yang menjadi responden sudah dapat membaca dan menulis yang dibuktikan dengan tamatnya kader dari bangku pendidikan minimal SD/sederajat. Kader posyandu harus dapat membaca dan menulis karena salah satu tugas kader adalah melakukan pencatatan dan pelaporan, serta membantu melakukan konseling/penyuluhan kesehatan kepada masyarakat. Menurut Muzzakir tingginya tingkat pendidikan formal kader akan mematangkan pemahaman tentang posyandu sehingga kinerja kader dapat meningkat juga. ${ }^{9}$

Tabel 2. Sebaran kader posyandu berdasarkan tingkat pengetahuan terkait informasi dasar posyandu sebelum kegiatan penyegaran kader

\begin{tabular}{|c|c|c|c|c|c|}
\hline \multirow{2}{*}{ Variabel } & \multicolumn{4}{|c|}{$\begin{array}{c}\text { Jumlah (\%) Responden Berdasarkan Pengetahuan } \\
\text { Sebelum Penyegaran }\end{array}$} & \multirow[t]{2}{*}{ Nilai $p^{*}$} \\
\hline & Kurang (\%) & Cukup (\%) & Baik $(\%)$ & Total $(\%)$ & \\
\hline \multicolumn{6}{|l|}{ Umur } \\
\hline Dewasa & $7(19,4)$ & $19(52,8)$ & $10(27,8)$ & $36(100)$ & \multirow{2}{*}{0,684} \\
\hline Pra Lansia & $3(20,0)$ & $9(60,0)$ & $3(20,0)$ & $15(100)$ & \\
\hline \multicolumn{6}{|l|}{ Pendidikan Terakhir } \\
\hline Tamat SD/sederajat & $3(75,0)$ & $1(25,0)$ & $0(0)$ & $4(100)$ & \multirow{3}{*}{0,000} \\
\hline $\begin{array}{l}\text { Tamat SMP/ } \\
\text { sederajat }\end{array}$ & $6(46,2)$ & $6(46,2)$ & $1(7,6)$ & $13(100)$ & \\
\hline $\begin{array}{l}\text { Tamat } \\
\text { SMA/sederajat }\end{array}$ & $1(2,9)$ & $21(61,8)$ & $12(35,3)$ & $34(100)$ & \\
\hline \multicolumn{6}{|l|}{ Pekerjaan } \\
\hline Tidak Bekerja (IRT) & $8(17,8)$ & $25(55,6)$ & $12(26,6)$ & $45(100)$ & \multirow{2}{*}{0,395} \\
\hline Bekerja & $2(33,3)$ & $3(50,0)$ & $1(16,7)$ & $6(100)$ & \\
\hline \multicolumn{6}{|l|}{ Lama Menjadi Kader } \\
\hline$\leq 12$ bulan & $9(50,0)$ & $8(44,4)$ & $1(5,6)$ & $18(100)$ & \multirow{5}{*}{0,002} \\
\hline $13-36$ bulan & $0(0)$ & $7(53,8)$ & $6(46,2)$ & $13(100)$ & \\
\hline $37-60$ bulan & $0(0)$ & $2(33,3)$ & $4(66,7)$ & $6(100)$ & \\
\hline$>60$ bulan & $1(11,1)$ & $6(66,7)$ & $2(22,2)$ & $9(100)$ & \\
\hline Ragu-ragu (lupa) & $0(0)$ & $5(100)$ & $0(0)$ & $5(100)$ & \\
\hline
\end{tabular}

Sebagian besar responden $(88,2 \%)$ tidak bekerja atau berperan sebagai Ibu Rumah Tangga (IRT), sisanya $(11,8 \%)$ bekerja (Tabel 1). Pekerjaan responden yaitu pedagang $(5,9 \%)$, wiraswasta $(3,9 \%)$, dan pengelola PAUD $(2,0 \%)$. Sebagian responden yang bekerja $(50,0 \%)$ dan tidak bekerja $(55,6 \%)$ memiliki pengetahuan yang cukup terkait informasi dasar posyandu (Tabel 2).

Kader posyandu yang menjadi responden dalam penelitian ini didominasi oleh Ibu
Rumah Tangga (IRT) atau tidak memiliki pekerjaan utama selain mengurus keluarga. Hal ini sesuai dengan Buku Panduan Kader Posyandu yang diterbitkan oleh Kemenkes RI yang mengharapkan kader memiliki kemampuan dan waktu luang serta bersedia bekerja secara sukarela. ${ }^{1}$ Banyakya responden yang tidak bekerja memungkinkan beberapa responden untuk lebih fokus dalam menjalankan tugasnya sebagai kader posyandu yang aktif. 
Jika dilihat dari lamanya menjadi kader posyandu, hanya $35,3 \%$ responden saja yang tergolong sebagai kader baru dengan masa kerja tidak lebih dari 1 tahun $(\leq 12$ bulan). Sisanya, termasuk ke dalam kader lama dengan masa kerja 13 - 36 bulan sebanyak $25,5 \%$ dan $37-60$ bulan sebanyak 11,8\%. Terdapat juga responden yang sangat lama telah menjadi kader posyandu dengan masa kerja lebih dari 60 bulan (>5 tahun) yaitu sebanyak 17,6\% (Tabel 1). Responden yang memiliki pengetahuan dengan kategori cukup dan baik terkait informasi dasar posyandu didominasi oleh responden yang telah lama menjadi kader posyandu (lebih dari 1 tahun menjadi kader posyandu), sedangkan responden yang baru menjadi kader (kurang dari 1 tahun) sebagian besar memiliki pengetahuan yang kurang terkait informasi dasar posyandu sebelum penyegaran (Tabel 2).

Uji statistik membuktikan bahwa tingkat pendidikan dan lama menjadi kader berhubungan secara nyata terhadap pengetahuan responden terkait informasi dasar posyandu sebelum kegiatan penyegaran dilakukan. Umur dan pekerjaan tidak berhubungan dengan pengetahuan responden terkait informasi dasar posyandu.

Legi, et al. berpendapat bahwa tingginya jenjang pendidikan biasanya akan diiringi dengan peningkatan pengetahuan seseorang. ${ }^{7}$ Sekain pendidikan, lamanya seseorang menjadi kader akan mempengaruhi tingkat pengetahuan dan keterampilan kader dalam menjalankan tugasnya di posyandu. ${ }^{4}$ Laraeni dan Wiratni berpendapat bahwa seseorang yang sudah bertugas selama $5-10$ tahun menjadi kader posyandu merupakan kader yang aktif. ${ }^{10}$

Berbeda dengan hasil penelitian ini, penelitian yang dilakukan oleh Putra dan Yuliatni membuktikan bahwa lamanya seseorang menjadi kader posyandu belum tentu memiliki kinerja yang baik jika tidak diiringi dengan pelatihan. ${ }^{5}$ Hasil penelitian Hamariyana, et al. juga membuktikan bahwa tidak terdapat hubungan antara lama kerja menjadi kader dengan keterampilan kader posyandu khususnya dalam menilai kurva pertumbuhan balita. ${ }^{11}$

\section{Analisis Pemberian Informasi Dasar Posyandu terhadap Pengetahuan Kader}

Penyegaran atau refreshing kader posyandu merupakan salah satu kegiatan pelatihan yang bertujuan untuk menjaga serta meningkatkan pengetahuan kader posyandu dalam melakukan pelayanan di posyandu. ${ }^{10}$ Kegiatan ini berisi pemberian materi oleh instruktur/tenaga kesehatan terlatih. Materimateri yang diberikan berupa informasi dasar posyandu serta teknis kegiatan dan pelaksanaan posyandu yang terstandar.

Tabel 3. Jumlah (\%) responden yang dapat menjawab dengan benar setiap pertanyaan

\begin{tabular}{lcc}
\hline \multicolumn{1}{c}{ Pertanyaan } & \multicolumn{2}{c}{$\begin{array}{c}\text { Jumlah }(\%) \text { Responden yg } \\
\text { Menjawab Benar }\end{array}$} \\
\cline { 2 - 3 } & Pretest $(\%)$ & Posttest $(\%)$ \\
\hline 1. Kepanjangan dari POSYANDU & $38(74,5)$ & $41(78,4)$ \\
2. Definisi POSYANDU & $39(76,5)$ & $46(90,2)$ \\
3. Sasaran dalam kegiatan POSYANDU & $41(80,4)$ & $46(90,2)$ \\
4. Kepanjangan dari istilah BGM dalam POSYANDU & $25(49,0)$ & $41(80,4)$ \\
5. Kegiatan yang bukan merupakan kegiatan utama di POSYANDU & $43(84,3)$ & $45(88,2)$ \\
6. Urutan tahap-tahap pelaksanaan kegiatan di POSYANDU (Meja 1 & $23(45,1)$ & $34(66,7)$ \\
sampai Meja 5) & $19(37,3)$ & $42(82,4)$ \\
7. Tugas kader pada saat hari pelaksanaan POSYANDU & $42(82,4)$ & $47(92,2)$ \\
8. Kepanjangan dari istilah KMS dalam POSYANDU & $46(90,2)$ & $50(98,0)$ \\
9. Warna KMS yang diberikan kepada anak laki-laki & $38(74,5)$ & $50(98,0)$ \\
10.Definisi istilah 2T pada KMS &
\end{tabular}


Menurut Laraeni dan Wiratni mengutip pendapat Sandi, tujuan utama pelatihan adalah untuk mengembangkan keahlian seseorang sehingga pekerjaannya dapat diselesaikan dengan lebih cepat dan efektif, untuk mengembangkan keahlian dan pengetahuan sehingga pekerjaan dapat diselesaikan secara rasional, dan mengembangkan kemajuan kerja sama dengan sesama rekan kerja dan diluar kerja serta dengan pemimpin. ${ }^{10,12}$

Hasil pretest dan posttest menunjukkan bahwa persentase jumlah responden yang dapat menjawab dengan benar untuk masing-masing item pertanyaan mengalami peningkatan. Peningkatan tertinggi terdapat pada item pertanyaan ke-7 yaitu "Tugas Kader pada Saat Hari Pelaksanaan Posyandu" dengan peningkatan sebesar $45.1 \%$. Selain itu, setelah kegiatan penyegaran, lebih dari setengah responden dapat menjawab dengan benar masing-masing 10 item pertanyaan yang berhubungan dengan informasi dasar posyandu (Tabel 3).

Hasil penelitian ini menunjukkan bahwa dengan adanya kegiatan penyegaran, persentase jumlah responden yang awalnya hanya sedikit yang dapat menjawab masing-masing pertanyaan, kemudian mengalami peningkatan. Sebagian besar responden yang tidak mengetahui tugasnya sebagai kader pada saat hari pelaksanaan posyandu secara jelas, berubah menjadi hampir seluruhnya mengetahui tugasnya sebagai kader setelah kegiatan penyegaran dilakukan (Tabel 3).

Laraeni dan Wiratni berpendapat bahwa tingkat pengetahuan dalam domain kognitif memiliki 6 tingkatan yaitu tahu, memahami, aplikasi, analisis, sintesis, dan evaluasi. Pemberian informasi dasar posyandu melalui kegiatan penyegaran kader kepada responden dianggap berhasil dan dapat meningkatkan pengetahuan responden khususnya terkait informasi dasar posyandu secara signifikan. Dimensi domain kognitif yang tersentuh dalam kegiatan penyegaran ini adalah tahu dan memahami. Hasil studi tersebut menunjukkan bahwa penyegaran kader dapat meningkatkan tingkat pengetahuan kader secara signifikan. ${ }^{10,13}$
Sebelum kegiatan penyegaran kader dilakukan, persentase responden terbesar terdapat pada responden dengan pengetahuan yang cukup terkait informasi dasar posyandu $(54,9 \%)$. Setelah kegiatan penyegaran diberikan, persentase terbesar terdapat pada responden dengan pengetahuan yang baik terkait informasi dasar posyandu $(66,7 \%)$ dan hanya tersisa sedikit sekali $(3,9 \%)$ responden yang memiliki pengetahuan yang kurang terkait informasi dasar posyandu (Gambar 1). Uji tes berpasangan (Paired t test) membuktikan bahwa terdapat perbedaan rata-rata antara skor pengetahuan sebelum dengan setelah pemberian informasi dasar posyandu melalui kegiatan penyegaran kader dengan nilai " $p=0,000$ " $(\mathrm{p}<0,05)$. Artinya, pemberian materi informasi dasar posyandu melalui kegiatan penyegaran kepada responden dalam penelitian ini dapat meningkatkan pengetahuan responden.

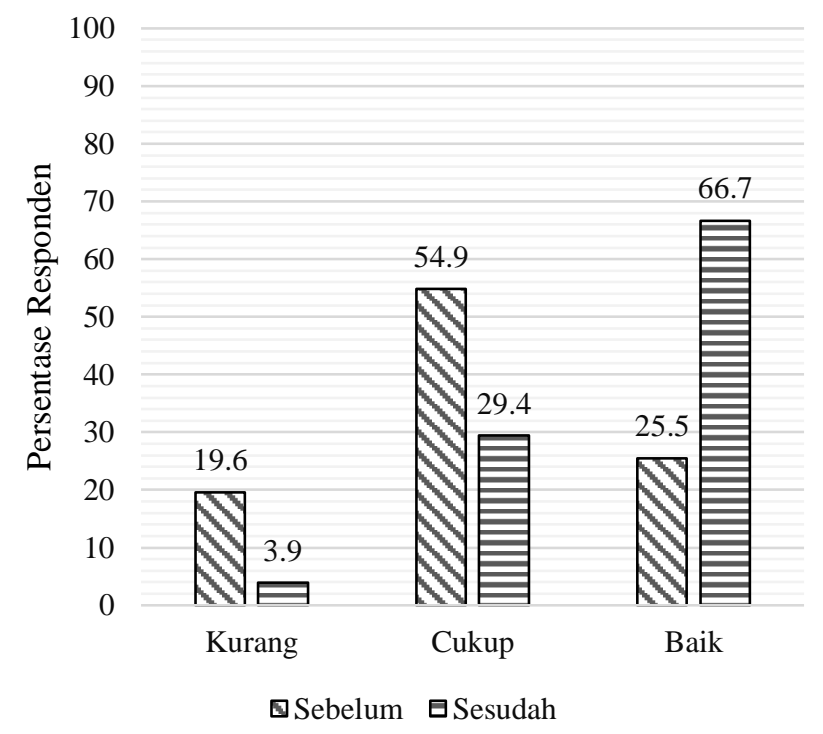

\section{Gambar 1. Persentase pengetahuan informasi dasar posyandu}

Hasil uji statistik membuktikan bahwa hanya tingkat pendidikan yang berhubungan secara signifikan dengan perubahan tingkat pengetahuan responden terkait informasi dasar posyandu sebelum dan setelah kegiatan penyegaran dengan nilai $\mathrm{p}<0,05$. Umur, pekerjaan, dan lama menjadi kader tidak berhubungan dengan perubahan tingkat pengetahuan responden terkait informasi dasar 
posyandu sebelum dan setelah kegiatan penyegaran dengan nilai $p>0,05$ (Tabel 4).

Tabel 4. Hubungan antara karakteristik dengan pengetahuan responden setelah intervensi pemberian materi informasi dasar posyandu

\begin{tabular}{lcc}
\hline \multirow{2}{*}{$\begin{array}{c}\text { Variabel } \\
\text { Karakteristik } \\
\begin{array}{c}\text { Responden } \\
\text { (independent) }\end{array}\end{array}$} & $\begin{array}{c}\text { Variabel Perubahan } \\
\text { Tingkat Pengetahuan } \\
\text { Responden (dependent) }\end{array}$ \\
\cline { 2 - 3 } & p-value & $\begin{array}{c}\text { Perbandingan } \\
\text { dengan } \alpha=5 \%\end{array}$ \\
\hline Umur & 0,952 & $>0,05$ \\
Pendidikan & 0,000 & $<0,05$ \\
Pekerjaan & 0,614 & $>0,05$ \\
Lama Menjadi & 0,051 & $>0,05$ \\
Kader & & \\
\hline
\end{tabular}

Tingkat pendidikan memiliki hubungan yang sangat signifikan terhadap peningkatan tingkat pengetahuan responden dalam penelitian ini. Legi, et al. berpendapat bahwa pendidikan merupakan suatu proses yang bertujuan untuk merubah perilaku manusia. ${ }^{7}$ Pendidikan yang lebih tinggi dapat membantu dalam menyerap informasi yang disampaikan pada saat intervensi pemberian materi informasi dasar posyandu. Semakin tinggi pendidikan, maka akan semakin mudah bagi seseorang untuk dapat menerima dan memahami setiap informasi yang diperoleh untuk dapat diaplikasikan dalam kehidupan sehari-harinya. Laraeni dan Wiratni menambahkan bahwa kader dengan pendidikan formal yang tinggi akan lebih mudah untuk mengerti dan memahami segala sesuatu yang diperolehnya baik pada waktu mengikuti pelatihan maupun pada waktu pelaksanaan kegiatan posyandu. ${ }^{10}$

\section{KESIMPULAN}

Pemberian materi informasi dasar posyandu melalui kegiatan penyegaran kader posyandu melalui metode ceramah dan tanya jawab menggunakan media gambar slide show power point dapat meningkatkan pengetahuan kader khususnya terkait informasi dasar posyandu secara signifikan. Tingkat pendidikan kader secara signifikan berhubungan dengan peningkatan pengetahuan kader terkait informasi dasar posyandu.

Pemilihan kader posyandu sebaiknya memperhatikan tingkat pendidikan kader karena berkaitan erat dengan daya terima terhadap informasi yang ada. Selain itu, perlu dilakukan penyegaran kader posyandu di puskesmas minimal dua tahun sekali untuk menjaga dan meningkatkan pengetahuan kader posyandu. Disarankan untuk melakukan penelitian dengan durasi intervensi lebih panjang dan dengan variabel yang berbeda.

\section{UCAPAN TERIMA KASIH}

Terimakasih kepada UPTD Puskesmas Pelabuhan Sambas dan Bidang Kesehatan Masyarakat Dinas Kesehatan Kota Sibolga yang telah memberikan izin dalam penggunaan data untuk analisis ini. Terimakasih dan apresiasi yang sebesar-besarnya disampaikan juga kepada Bapak H. M. Syarfi Hutauruk selaku Walikota Sibolga yang telah mendukung dan mengarahkan kegiatan ini.

\section{KEPUSTAKAAN}

1. Kementerian Kesehatan RI. Kurikulum Dan Modul Pelatihan Kader Posyandu.; 2012.

2. Fadjri TK. Kualitas Hasil Penimbangan Berat Badan Balita oleh Kader Posyandu. AcTion: Aceh Nutrition Journal. 2016;1(2):111-115. http://dx.doi.org/10.30867/action.v1i2.20

3. Dinas Kesehatan Sibolga. Profil Kesehatan Kota Sibolga Tahun 2018.; 2018.

4. Sutiani R, Lubis Z, Siagian A. Gambaran Pengetahuan dan Keterampilan Kader Posyandu dalam Pemantauan Pertumbuhan Bayi dan Balita di Wilayah Kerja Puskesmas Desa Lalang Tahun 2014. Jurnal Universitas Sumatera Utara. 2015;2015:1-8.

5. Putra GTB, Yuliatni PCD. Gambaran Pengetahuan Dan Kinerja Kader Posyandu Di Wilayah Kerja UPT Puskesmas Mengwi I Kabupaten Badung pada Bulan Juli - 
Agustus 2015. E-Jurnal Medika. 2016;5(10):1-9.

6. Sandiyani RA, Mulyani T. Lama Menjadi Kader, Frekuensi Pelatihan, Pengetahuan Gizi, dan Sikap Kader Posyandu dengan Perilaku Penyampaian Informasi tentang Pesan Gizi Seimbang. 2011.

7. Legi NN, Rumagit F, Montol AB, Lule R. Faktor yang Berhubungan Dengan Keaktifan Kader Posyandu di Wilayah Kerja Puskesmas Ranotana Weru. GIZIDO. 2015;7(2):429-437.

8. Hapsari HT, Veria VA. Faktor-Faktor yang Berhubungan dengan Keaktifan Kader Posyandu di Wilayah Kerja Puskesmas Slawi tahun 2015. SIADIN. 2015.

9. Muzakkir H. Faktor-Faktor yang Berhubungan dengan Kinerja Kader Posyandu di Wilayah Kerja UPTD Puskesmas Kaledupa Kecamatan Kaledupa Kabupaten Wakatobi Propinsi Sulaweesi Tenggara. Jurnal Ilmiah Kesehatan Diagnosis. 2013;2(2):1-7.

10. Laraeni Y, Wiratni A. Pengaruh Penyegaran Kader Terhadap Pengetahuan Dan Keterampilan Kader Posyandu Menggunakan Dacin Di Wilayah Kerja
Puskesmas Dasan Cermen Kecamatan Sandubaya Kota Mataram. Media Bina Ilmiah. 2014;8(4):44-52.

11. Syamsianah A, Winaryati E. Hubungan Pengetahuan dan Lama Kerja Dengan Ketrampilan Kader Dalam Menilai Kurva Pertumbuhan Balita di Posyandu Kelurahan Tegalsari Kecamatan Candisari Kota Semarang. Jurnal Gizi. 2013;2(1).

12. Sandi F, Aritonang EY, Jumirah. Pengaruh Pelatihan terhadap Keterampilan Kader dalam Pembuatan PMT Modisco di Wilayah Kerja Puskesmas Pematang Panjang, Kecamatan Air Putih, Kabupaten Batubara Tahun 2012. Gizi, Kesehatan Reproduksi dan Epidemiologi. 2012;1(2):1-9.

13. Hardiyanti R, Jus'at I, Angkasa D. Hubungan lama kerja menjadi kader, pengetahuan, pendidikan, pelatihan dengan presisi dan akurasi hasil penimbangan berat badan balita oleh kader Posyandu. AcTion: Aceh Nutrition Journal. 2018;3(1):74-81. http://dx.doi.org/10.30867/action.v3i1.102 